\title{
The causes of the lack of self-tolerance of winter rye grown on light sandy soils. 3. Effects of soil fungi
}

\author{
K. Scholte, L. J. P. Kupers and A. J. Scholten*
}

Department of Field Crops and Grassland Science, Agricultural University, Haarweg 333, 6709 RZ Wageningen, Netherlands

Accepted: 26 June 1984

Key-words: rye, winter rye, self-tolerance, crop rotation, soil fungi; fungicides.

\section{Summary}

The application of a nematicide and two fungicides enabled the various causes of self-intolerance of rye grown in a sandy soil in a pot experiment to be discerned. Soil fungi appeared to be the major causal factor.

\section{Introduction}

In an earlier rotational field experiment laid out on a light sandy oil, winter rye appeared to be self-intolerant (Scholte \& Kupers, 1977). This self-intolerance of winter rye is also found by Steinbrenner et al. (1982) and Obenauf et al. (1982).

A series of field and pot experiments indicated that neither foot rot, nematodes nor phytotoxins could be important causes of this lack of self-tolerance (Scholte \& Kupers, 1977, 1978). At the same time it became clear that the main cause ought to be found in the soil microflora. Therefore a pot experiment was set up to prove, with the help of applications of a nematicide and two fungicides, that somehow soil fungi are responsible for the earlier described reduction in yield.

\section{Materials and methods}

The only difference between the two batches of soil used in this pot trial was that rye had been the preceding crop on one batch, whereas the other had supported a crop of oats.

The crop sequence in the three years preceding this pot trial (1977-1979) and in the year of the trial itself (1980) was:

$\begin{array}{llll}1977(\text { field }) & 1978(\text { field }) & 1979(\text { field }) & 1980 \text { (pots) } \\ \text { rye } & \text { maize } & \text { oats } & \text { rye } \\ \text { rye } & \text { potato } & \text { rye } & \text { rye }\end{array}$

* Present adress: Nickerson Zwaanesse B.V., Huissitterweg 7, 2266 HE Stompwijk. Netherlands 
Table 1. Timing and rates of application of pesticides.

\begin{tabular}{|c|c|c|c|c|c|c|}
\hline \multirow[t]{2}{*}{ Date } & \multirow[t]{2}{*}{$\begin{array}{l}\text { Growth stage } \\
\text { (Feekes scale) }\end{array}$} & \multirow{2}{*}{ 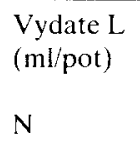 } & \multicolumn{2}{|c|}{$\begin{array}{l}\text { Benlate } \\
\text { (mg/pot) }\end{array}$} & \multicolumn{2}{|c|}{$\begin{array}{l}\text { Ortho-difolatan } 4 \mathrm{~F} \\
\text { (mg/pot) }\end{array}$} \\
\hline & & & $F_{1}$ & $\mathrm{~F}_{2}$ & $F_{1}$ & $F_{2}$ \\
\hline $18 / 10 / 79$ & 0 & 0.1 & - & - & - & - \\
\hline $11 / 12 / 79$ & 1 & - & 50 & 150 & - & - \\
\hline $07 / 01 / 80$ & 2 & - & - & - & 0.3 & 0.6 \\
\hline $27 / 02 / 80$ & 3 & - & 50 & 150 & - & - \\
\hline $20 / 03 / 80$ & 4 & 0.1 & - & - & - & - \\
\hline $22 / 04 / 80$ & 7 & - & - & - & 0.3 & 0.6 \\
\hline $02 / 05 / 80$ & 8 & - & 50 & 150 & - & - \\
\hline $28 / 05 / 80$ & 10.5 & - & - & - & 0.3 & 0.6 \\
\hline $11 / 06 / 80$ & 10.5 .4 & - & 50 & 150 & - & - \\
\hline Total & & 0.2 & 200 & 600 & 0.9 & 1.8 \\
\hline
\end{tabular}

Untreated soils derived from both crop sequences were compared with the same soils that had been treated with the nematicide Vydate L (oxamyl) and/or a number of applications of the fungicides Benlate (benomyl) and Ortho-difolatan 4F (captafol). The timing and doses of the applications are given in Table 1.

One week before the sowing date, the soil was collected from the field. Black pots, volume 5.51 , were filled with sieved and homogenized soil. These pots were placed inside white enamelled pots. The layer of air between the sides of the pots ensured that the soil temperature during the growing season remained fairly constant.

Sowing date was 17 October 1979. Seeds were treated with Panoctine 35 (guazatine). Per pot 25 seeds were sown. After emergence the number of plants per pot was reduced to 12 .

The cultivar used was Dominant. During winter the pots were kept in an unheated glasshouse $\left(-4^{\circ} \mathrm{C},+10^{\circ} \mathrm{C}\right)$. At the end of February the pots were placed outdoors.

The following amounts of nutrients were applied per pot, apportioned over four applications from sowing date to anthesis: $2240 \mathrm{mg} \mathrm{N}, 620 \mathrm{mg} \mathrm{P}, 2340 \mathrm{mg} \mathrm{K}, 288 \mathrm{mg}$ $\mathrm{Mg}$ and $8 \mathrm{ml}$ of trace element solution (with $\mathrm{Cu}, \mathrm{Mn}, \mathrm{Zn}, \mathrm{Mo}$ and $\mathrm{B}$ ).

The final harvest took place at 23 July 1980.

\section{Results}

\section{Foot rot}

Foot rot diseases were assessed just prior to anthesis and before the final harvest. At both these stages of growth a few haulms were found to be affected. There was no correlation between the incidence of disease and the preceding crop, nor between disease and treatments. 


\section{Nematodes}

Immediately prior to anthesis the number of endo-parasitic nematodes were counted. Pratylenchus crenatus was found, accompanied by small numbers of $P$. fallax. The ecto-parasitic nematode Tylenchorhynchus dubius and the cyst-forming nematode Heterodera avenae were also present. The data on the numbers of nematodes are presented in Table 2 (except for $H$. avenae: very few cysts of this nematode were found and the numbers were independent of the preceding crop).

From Table 2 it can be seen that in untreated pots both Pratylenchus and Tylenchorhynchus were numerous when grown in soil in which the preceding crop had been rye (henceforth these pots will be referred to as rye-rye pots: pots containing soil in which the preceding crop was oats will be referred to as oats-rye pots).

Application of the nematicide Vydate L drastically reduced Pratylenchus in all pots. The population of Tylenchorhynchus was reduced by $94 \%$. The fungicides had mostly a negative effect on the population densities of both nematodes.

\section{The yields}

Table 3 shows that the crop yields in the untreated rye-rye pots were much lower than those in the untreated oats-rye pots: the grain yield was more than $18 \%$ lower

Table 2. Number of nematodes in untreated soil (C) and in soil treated with a nematicide (N) or fungicides $\left(F_{1}\right.$ and $F_{2}$, see Table 1$)$ at growth stage 10.5 (Feekes scale).

\begin{tabular}{|c|c|c|c|c|c|c|c|c|}
\hline \multirow{2}{*}{$\begin{array}{l}\text { Predecing } \\
\text { crop }\end{array}$} & \multicolumn{4}{|c|}{ Pratylenchus spp. $/ 10 \mathrm{~g}$ roots } & \multicolumn{4}{|c|}{ Tylenchorhynchus dubius $/ 100 \mathrm{ml}$ soil } \\
\hline & $\mathrm{C}$ & $N$ & $F_{1}$ & $\mathrm{~F}_{2}$ & $\mathrm{C}$ & $N$ & $F_{1}$ & $\mathrm{~F}_{2}$ \\
\hline Oats & 650 & 10 & 210 & 490 & 520 & 30 & 860 & 360 \\
\hline Rye & 2120 & 0 & 280 & 410 & 810 & 60 & 250 & 200 \\
\hline
\end{tabular}

Table 3. Yields of rye in relation to preceding crop, in untreated (C) soil and in soil treated with a nematicide $(N)$ or fungicides $\left(F_{1}\right.$ and $F_{2}$, see Table 1$)$.

\begin{tabular}{|c|c|c|c|c|c|c|c|}
\hline \multirow{2}{*}{$\begin{array}{l}\text { Soil } \\
\text { treatment }\end{array}$} & \multirow{2}{*}{$\begin{array}{l}\text { Preceding } \\
\text { crop }\end{array}$} & \multirow{2}{*}{$\begin{array}{l}\text { Number of } \\
\text { ears/pot }\end{array}$} & \multirow{2}{*}{$\begin{array}{l}\text { Number of } \\
\text { grains/ear }\end{array}$} & \multirow{2}{*}{$\begin{array}{l}1000 \text {-grain } \\
\text { weight }(\mathrm{g})\end{array}$} & \multicolumn{3}{|c|}{ Yield in $\mathrm{g} \mathrm{dm} /$ pot } \\
\hline & & & & & straw & grain & total \\
\hline \multirow[t]{2}{*}{$\mathrm{C}$} & oats & 29.2 & 56.9 & 35.3 & 97.1 & 59.0 & 156.1 \\
\hline & rye & $24.8^{* *}$ & 56.0 & 34.6 & $86.3^{* *}$ & $48.2^{* *}$ & $134.5^{* *}$ \\
\hline \multirow[t]{2}{*}{ N } & oats & 29.7 & 60.2 & 34.1 & 102.1 & 61.0 & 163.1 \\
\hline & rye & 29.7 & 56.9 & 32.5 & $87.9^{* *}$ & $54.6^{*}$ & $142.5^{* *}$ \\
\hline \multirow[t]{2}{*}{$\mathrm{F}_{1}$} & oats & 35.2 & 55.9 & 35.3 & 110.7 & 69.1 & 179.8 \\
\hline & rye & 33.7 & 53.8 & 34.6 & 109.8 & $62.4^{*}$ & 172.2 \\
\hline \multirow[t]{2}{*}{$\mathrm{F}_{2}$} & oats & 33.8 & 56.8 & 36.1 & 113.4 & 68.9 & 182.3 \\
\hline & rye & 35.7 & 53.3 & 34.7 & 110.8 & 65.4 & 176.2 \\
\hline
\end{tabular}

${ }^{*}$ or ${ }^{* *}$ values of rye-rye differ significantly from values of oats-rye within a treatment at $P<0.05$ or $P<$ 0.01 , respectively.

Neth. J. agric. Sci. 32 (1984) 
and the straw yield more than $11 \%$ lower. This lower yield was mainly attributed to the lower number of ears per pot. However, the number of grains per ear and the 1000 -grain weight were also lower in the untreated rye-rye pots.

Treating the soil with the nematicide Vydate $\mathrm{L}$ led to an increase in total dry matter yield by well over $5 \%$ (significant at $P<0.07$ ) in rye-rye as well as in oats-rye pots: this yield increase was almost the same for each. In the rye-rye pots the increase in yield mainly resulted from an increase in the number of ears per pot. This increase in the number of ears per pot was due to small ears arising from late sprouts. Therefore, the analysis of the yield of rye-rye pots treated with the nematicide shows fewer grains per ear and a lower 1000-grain weight than the untreated oats-rye pots.

In both the rye-rye and oats-rye pots, treating the soil with fungicides produced a marked increase in yields. No difference was observed between the above-ground effects of the two fungicide applications $\left(\mathrm{F}_{1}\right.$ and $\left.\mathrm{F}_{2}\right)$. However, there was a significant $(P<0.05)$ correlation between preceding crop and fungicide application. The increase in the yield of rye-rye pots was larger than that of oats-rye pots. The yield difference was $13.5 \%$ in the untreated pots but was only 3-4\% in the treated pots (Table 4). This decrease in loss of yield resulted from a reduction in the yield loss of the straw (from $11 \%$ to $2.6 \%$ ) and a reduction in the yield loss in grains (from $18.3 \%$ to $7.4 \%$ ). In the pots that had been treated with the fungicides, the same number of ears were produced per pot irrespective of preceding crop (Table 3 ). The disparity in the number of grains per ear in the rye-rye pots compared with the oats-rye pots increased slightly.

No significant correlation was found between nematicide and fungicide applications (Table 4).

\section{Roots: quantity and quality}

Before the onset of anthesis (growth stage 10.5, according to the Feekes scale) and also at final harvest (growth stage 11.2), root quantity and quality were estimated. The data on root mass are presented in Table 5. Just prior to anthesis there were no clear differences in root mass between the untreated rye-rye pots and the untreated oats-rye pots.

By comparison with their untreated counterparts, the root masses of the treated

Table 4. Total yield of rye in $\mathrm{g} \mathrm{dm}$ per pot, in relation to preceding crop, in untreated soil (C) and in soil treated with a nematicide $(\mathrm{N})$ and/or fungicides $\left(\mathrm{F}_{1}\right.$ and $\mathrm{F}_{2}$, see Table 1$)$.

\begin{tabular}{llccccc}
\hline Preceding crop & \multicolumn{7}{l}{ Treatments } & \multicolumn{1}{l}{} & \\
\cline { 2 - 7 } & $\mathrm{C}$ & $\mathrm{N}$ & $\mathrm{F}_{1}$ & $\mathrm{~F}_{2}$ & $\mathrm{NF}_{1}$ & $\mathrm{NF}_{2}$ \\
Oats & 156 & 163 & 180 & 182 & 182 & 188 \\
Rye & $135^{* *}$ & $142^{* *}$ & 172 & 176 & 172 & 179 \\
Reduction in \% & 13.5 & 12.7 & 4.3 & 3.3 & 5.6 & 4.5 \\
\hline
\end{tabular}

${ }^{* *}$ Values of rye-rye differ significantly from values of oats-rye within a treatment at $P<0.01$. 
Table 5. Root mass in $\mathrm{g} \mathrm{dm}$ per pot, in relation to preceding crop and growth stage (Feekes scale), in untreated soil $(\mathrm{C})$ and in soil treated with a nematicide $(\mathrm{N})$ or fungicides $\left(\mathrm{F}_{1}\right.$ and $\mathrm{F}_{2}$, see Table 1$)$.

\begin{tabular}{|c|c|c|c|c|c|c|c|c|}
\hline \multirow{2}{*}{$\begin{array}{l}\text { Preceding } \\
\text { crop }\end{array}$} & \multicolumn{4}{|c|}{ Growth stage 10.5} & \multicolumn{4}{|c|}{ Growth stage 11.3} \\
\hline & $\mathrm{C}$ & $\mathrm{N}$ & $\mathrm{F}_{1}$ & $\mathrm{~F}_{2}$ & $\mathrm{C}$ & $N$ & $F_{1}$ & $\mathrm{~F}_{2}$ \\
\hline Oats & 10.3 & 12.0 & 10.7 & 10.2 & 12.4 & 9.1 & 15.7 & 10.8 \\
\hline Rye & 10.5 & $8.7^{*}$ & 8.5 & 8.2 & $5.1^{* *}$ & $5.5^{* *}$ & $10.1^{* *}$ & $8.1^{*}$ \\
\hline
\end{tabular}

" or ** values of rye-rye differ significantly from values of oats-rye within a treatment at $P<0.05$ or $P<$ 0.01 , respectively.

oats-rye pots were slightly heavier, whereas those of the treated rye-rye pots were slightly lighter.

During the grain filling and ripening phase the roots in untreated rye-rye pots degenerated rapidly. The roots in untreated oats-rye pots, however, stayed reasonably intact. This process could be followed easily by growing plants in transparent perspex tubes (Fig. 1). During the experiment these perspex tubes were covered with opaque PVC tubes.

At final harvest the roots of rye-rye were grey and the finer roots had already disappeared during the washing-out of the root system. The root mass of the rye-rye

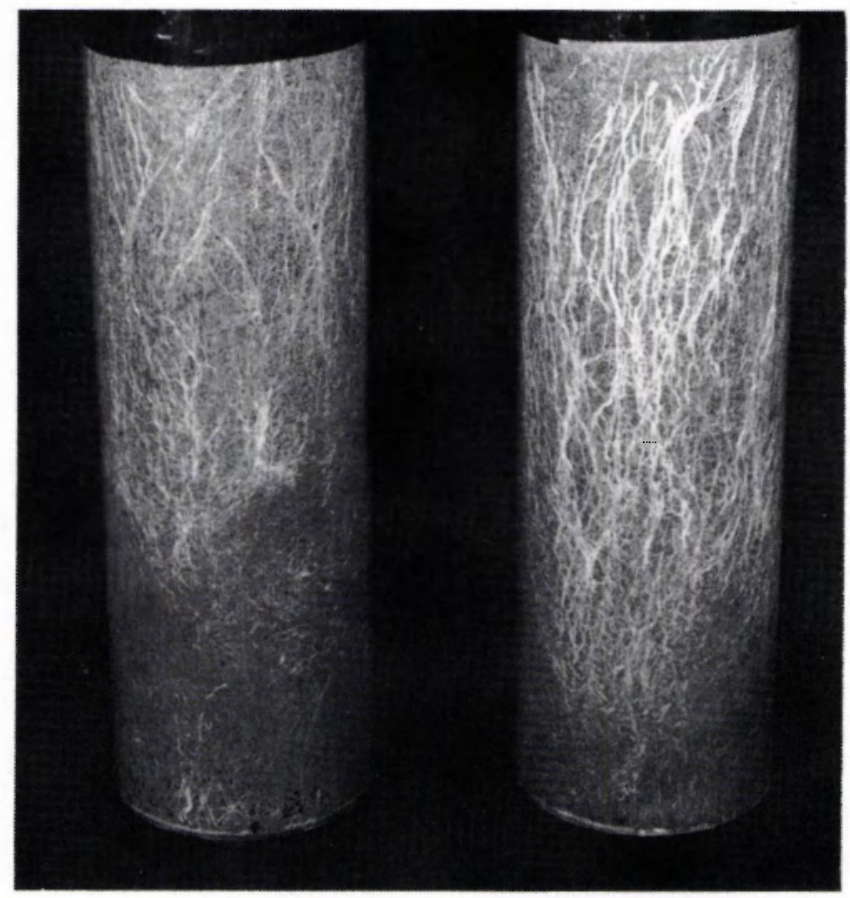

Fig. 1. Root system of rye-rye (left) compared with oats-rye (right) at final harvest.

Neth. J. agric. Sci. 32 (1984) 


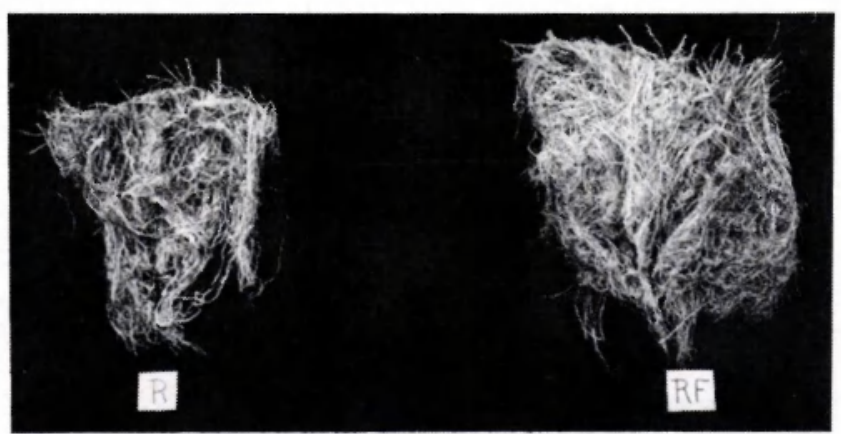

Fig. 2. Root system of rye grown after rye in untreated soil (left) and in soil treated with fungicides (right) at final harvest.

plants had fallen to half of the weight at the onset of anthesis (Table 5). At final harvest the colour of the roots of plants in the oats-rye pots was brighter: the root mass of these plants did not decline appreciably during grain filling and ripening.

In this experiment the quality of the roots was estimated on the basis of colour and the presence of fine roots. The treatment with nematicide did not halt the reduction in root quality. However, applying fungicides to the soil had a very clear effect on the root quality of rye-rye plants (Fig. 2): it prevented the premature degeneration of the root system after anthesis. The qualitative and quantitative differences between the root masses of rye-rye pots and oats-rye pots were considerably less if the pots had been treated with fungicides.

The higher doses of fungicides $\left(\mathrm{F}_{2}\right)$ in all treatments had a slight phytotoxic effect. This was inferred from the fact that the root mass of pots that received higher doses of fungicides $\left(\mathrm{F}_{2}\right)$ was lower than the root mass of pots that received the lower doses $\left(F_{1}\right)$ (Table 5).

\section{Discussion}

From the evidence presented one may conclude that when grown on light sandy soils, rye following rye suffers a drastic decline in yield. Analysis of the yield indicates that this yield depression is related to a reduction in numbers of ears per pot and a reduced 1000-grain weight. The reduction in numbers of haulms suggests that this is primarily caused by less root activity in the pre-anthesis stage, whereas during this stage no differences in root mass were found. The hypothesis that the root system fails at an early stage is strongly supported by the clear reduction in 1000 grain weight at final harvest. Though it was very evident that at the end of the grainfilling phase the root system of the untreated rye-rye pots was inferior in quantity as well as in quality, the onset of the decay of the root system must have started much earlier in the growing season. This would also explain the difference of $11 \%$ in straw yield.

The set-up of this experiment ensured that foot rots could not have been the cause of the deterioration of the root system. However, it is conceded that in pot ex- 
periments conditions may be less favourable for the occurrence of foot rot than in the open field.

In this experiment, plant-parasitic nematodes can be excluded as an important cause of the depression in yield, because though treating the soil with a nematicide gave excellent control of the nematodes, the appreciable difference in yield between rye-rye and oats-rye pots remained. Furthermore, root quality was no better in pots treated with nematicide.

Applications of repeated doses of fungicides reduced the yield loss to zero. Earlier it was stated that foot rots can be discounted, at least in this experiment as a cause of yield depression. Therefore, the broad spectrum fungicides used in this experiment must have controlled a group of soil fungi that had apparently risen to a pathogenic level in numbers or in virulence as a result of the crop sequence. To prove that fungi are the cause of self-intolerance of rye was precisely the aim of the experiment. We have thus confirmed the hypothesis we put forward in a previous publication (Scholte \& Kupers, 1978).

The fungicides were applied several times during the growing season to prevent them from being rapidly degrated by the soil microflora. Since broad spectrum fungicides were used and several applications were made, the group or sucessive groups of fungi that might have caused the gradual destruction of the root system cannot be identified.

\section{Conclusion}

In modern high-input and high-yield agriculture, winter rye grown after winter rye on sandy soils suffers appreciably compared to winter rye following other crops. This loss of yielding capacity is not necessarily caused by the wellknown plant pathogenic organisms: it is caused by an attack on the root system. A group or groups of fungi, maybe even operating successively, gradually destroys the root system. The virulence of the pathogen seems to be strongly related to the frequency at which the crop occurs in the rotation.

\section{References}

Steinbrenner, K., H. J. Liste \& G. Kühn, 1982. Die Stellung des Getreides in der Fruchtfolge und der Einfluss der Vorfrucht auf den Ertrag von Winterweizen, Wintergerste, Winterroggen, Sommergerste und Hafer. Archiv für Acker- und Pflanzenbau und Bodenkunde, Berlin 26 (3)183-192.

Obenauf, U., K. Steinbrenner \& R. Roth, 1982. Einfluss ausgewählter Intensivierungsmassnahmen auf Ertrag und Ertragskomponenten von Winterweizen und Winterroggen in Fruchtfolgen mit unterschiedlichen Getreide-anteil auf D-Standorten. Archiv für Acker-und Pflanzenbau und Bodenkunde, Berlin $26(9) 589-598$.

Scholte, K. \& L. J. P. Kupers, 1977. The causes of the lack of self-tolerance of winter rye, grown on light sandy soils. 1. Influence of foot rots and nematodes. Netherlands Journal of Agricultural Science 25: 255-262.

Scholte, K. \& L. J. P. Kupers, 1978. The causes of the lack of self-tolerance of winter rye, grown on light sandy soils. 2. Influences of phytotoxins and soil microflora. Netherlands Journal of Agricultural Science 26: $250-266$. 